\title{
Effect of bleaching whey on sensory and functional properties of $80 \%$ whey protein concentrate ${ }^{1}$
}

\author{
S. Jervis, ${ }^{\star}$ R. Campbell,, ${ }^{\star}$ K. L. Wojciechowski, $†$ E. A. Foegeding, ${ }^{\star}$ M. A. Drake, ${ }^{\star 2}$ and D. M. Barbano† \\ *Department of Food, Bioprocessing and Nutritional Sciences, Southeast Dairy Foods Research Center, North Carolina State University, \\ Raleigh 27695 \\ †Northeast Dairy Foods Research Center Department of Food Science, Cornell University, Ithaca, NY 14853
}

\begin{abstract}
Whey is a highly functional food that has found widespread use in a variety of food and beverage applications. A large amount of the whey proteins produced in the United States is derived from annatto-colored Cheddar cheese. Color from annatto is undesirable in whey and must be bleached. The objective of this study was to compare 2 commercially approved bleaching agents, benzoyl peroxide (BP) and hydrogen peroxide (HP), and their effects on the flavor and functionality of $80 \%$ whey protein concentrate (WPC80). Colored and uncolored liquid wheys were bleached with $\mathrm{BP}$ or HP, and then ultrafiltered, diafiltered, and spray-dried; WPC80 from unbleached colored and uncolored Cheddar whey were manufactured as controls. All treatments were manufactured in triplicate. The WPC80 were then assessed by sensory, instrumental, functionality, color, and proximate analysis techniques. The HP-bleached WPC80 were higher in lipid oxidation compounds (specifically hexanal, heptanal, octanal, nonanal, decanal, dimethyl disulfide, and 1-octen-3-one) and had higher fatty and cardboard flavors compared with the other unbleached and BP-bleached WPC80. The WPC80 bleached with BP had lower norbixin concentrations compared with WPC80 bleached with HP. The WPC powders differed in Hunter color values (L, a, b), with bleached powders being more white, less red, and less yellow than unbleached powders. Bleaching with BP under the conditions used in this study resulted in larger reductions in yellowness of the powders made from whey with annatto color than did bleaching with HP. Functionality testing demonstrated that whey bleached with HP treatments had more soluble protein after 10

\footnotetext{
Received September 22, 2011.

Accepted February 9, 2012.

${ }^{1}$ Use of names, names of ingredients, and identification of specific

${ }^{2}$ Corresponding author: maryanne_drake@ncsu.edu
} models of equipment is for scientific clarity and does not constitute any endorsement of product by authors, Cornell University, North Carolina State University, the Northeast Dairy Foods Research Center, or the Southeast Dairy Foods Research Center.
\end{abstract}

min of heating at $90^{\circ} \mathrm{C}$ at $\mathrm{pH} 4.6$ and $\mathrm{pH} 7$ than the no-bleach and BP treatments, regardless of additional color. Overall, HP bleaching caused more lipid oxidation products and subsequent off-flavors compared with BP bleaching. However, heat stability of WPC 80 was enhanced by HP bleaching compared with control or BP-bleached WPC80.

Key words: bleaching, whey protein, flavor

\section{INTRODUCTION}

Whey contains highly functional proteins that have found widespread use in food and beverage applications. The appealing functional properties of whey protein include solubility, water-binding ability, gelation, foaming, buffering, and emulsifying properties (Davis and Foegeding, 2007). Whey protein used in most food and beverage applications comes in 3 forms: whey powder, which can range in protein concentration from 11 to $14.5 \%$; whey protein concentrate (WPC), which can range in protein concentration from 35 to $89 \%$; and whey protein isolate (WPI), which contains $90 \%$ or greater protein concentration (USDEC, 2008).

Three sources of flavor variability in whey products can occur: lipid oxidation, process-induced changes, and fermentation by lactic acid bacteria and other cultures (Cadwallader and Singh, 2009). Lipid oxidation products, specifically aldehydes, free fatty acids, and methyl ketones, are primarily responsible for off-flavors in dried whey proteins (Carunchia Whetstine et al., 2005a; Wright et al., 2009; Whitson et al., 2010). Flavor variability in WPC80 has been attributed to milk source, starter culture, processing, and storage (Carunchia Whetstine et al., 2003; Tomaino et al., 2004; Gallardo-Escamilla et al., 2005; Croissant et al., 2009; Campbell et al., 2011b). Off-flavors in $80 \%$ whey protein concentrate (WPC80) and WPI have been characterized as cardboard, cabbage, and fatty/oxidized, and are attributed to lipid oxidation and protein degradation products (Carunchia Whetstine et al., 2005b; Wright et al., 2006; Croissant et al., 2009; Whitson et al., 2010; Listiyani et al., 2011). Whey proteins ideally have a 
bland flavor to enhance their ability to be used in a variety of food and beverage products (Drake, 2006; Drake et al., 2009; Wright et al., 2009).

A large amount of the dried whey protein in the United States is manufactured from Cheddar cheese whey colored with annatto. Annatto is a natural coloring agent derived from the outer seed coats of the tropical shrub Bixa orellana (Scotter, 2009). The major carotenoids responsible for the yellow color of annatto are bixin, which is soluble in nonpolar media, and norbixin, which is soluble in polar media. Norbixin is the primary carotenoid derived from annatto used for cheesemilk and the primary colorant in whey. Campbell et al. (2011a) recently demonstrated that annatto played no direct role in flavor of dried WPC. However, colored whey is generally bleached to achieve a whiter dried product suitable for a wide range of applications. Benzoyl peroxide (BP) and hydrogen peroxide (HP) are the 2 commercially approved bleaching agents used in the United States to bleach liquid whey. The bleaching step applied in the processing of whey protein may affect the flavor of WPC80. Croissant et al. (2009) demonstrated that HP-bleached liquid whey and WPC with $70 \%$ protein (WPC70) from HP-bleached whey had higher concentrations of lipid oxidation compounds compared with BP-bleached liquid whey and WPC70 from BP-bleached whey. Listiyani et al. (2011) likewise confirmed that volatile and sensory profiles of unbleached, HP-bleached, and BP-bleached WPC34 were distinct. The effect of these 2 different bleaching agents on the flavor and functional properties of WPC80 has not been determined. The objective of this study was to characterize and compare the composition, processing, sensory, and functional properties of WPC80 produced from bleached and unbleached Cheddar whey made from milk with and without added annatto color.

\section{MATERIALS AND METHODS}

\section{Experimental Design}

One batch of whole, raw bovine milk (about 1,000 $\mathrm{kg}$ ) was received from the Cornell University dairy farm on Monday and pasteurized at 72 to $73^{\circ} \mathrm{C}$ for $16 \mathrm{~s}$ and stored overnight at $4^{\circ} \mathrm{C}$. On Tuesday, Cheddar cheese was made and whey was collected from the cheese vat at draining, pasteurized at 72 to $73^{\circ} \mathrm{C}$ for $16 \mathrm{~s}$, cooled to $50^{\circ} \mathrm{C}$, separated with a centrifugal cream separator, and bleached after separation. The whey was cooled and held overnight at $4^{\circ} \mathrm{C}$. On Wednesday, the whey was heated to $50^{\circ} \mathrm{C}$ and then underwent ultrafiltration and diafiltration to produce a liquid $80 \%$ WPC, cooled to $4^{\circ} \mathrm{C}$, and held overnight. The liquid WPC was spray dried on Thursday. Each replicate of the experiment included 6 treatments. For the first 3 treatments within replicate 1, one vat of Cheddar cheese was made in each of 3 wk with no annatto color added to the milk. In wk 1 , the whey was not bleached, in wk 2 , the whey was bleached with BP, and in wk 3, the whey was bleached with HP. For the second 3 treatments within replicate 1 , one vat of Cheddar cheese was made in each of 3 wk with annatto color added to the milk. In wk 1, the whey was not bleached, in wk 2 , the whey was bleached with BP, and in wk 3, the whey was bleached with HP. This set of 6 treatments was replicated 3 times with different batches of raw milk for a total of 18 vats of cheese and 18 batches of WPC80.

\section{Cheddar Cheese Manufacture}

Raw whole milk for Cheddar cheese production was pasteurized with a plate heat exchanger (model 080-S, AGC Engineering, Manassas, VA) at 72 to $73^{\circ} \mathrm{C}$ and a holding time of $16 \mathrm{~s}$, cooled to $4^{\circ} \mathrm{C}$, and held overnight. The pasteurized milk was weighed into a cheese vat (model DLHD8SSS, Kusel Equipment Company, Watertown, WI) and heated to $30^{\circ} \mathrm{C}$. The milk was inoculated with the starter culture including Lactococcus lactis ssp. lactis and Lactococcus lactis ssp. cremoris (980 frozen pelleted culture, Chr. Hansen Inc., Milwaukee, WI) at the rate of $0.1 \mathrm{~g} / \mathrm{kg}$. The milk was agitated for $5 \mathrm{~min}$ and allowed to ripen for $30 \mathrm{~min}$. For the treatments with added annatto (Annatto cheese color 2X, P/N 70741, Chr. Hansen Inc.), it was added at a rate of $0.066 \mathrm{~mL} / \mathrm{kg}$ of milk. The ripened milk, $31^{\circ} \mathrm{C}$, was coagulated with double-strength chymosin (Chymax Extra, Chr. Hansen Inc.) for $30 \mathrm{~min}$ at a rate of $0.099 \mathrm{~mL} / \mathrm{kg}$ of milk. The coagulum was cut with 1.6-cm wire knives, the curd and whey was allowed to rest for $5 \mathrm{~min}$, and then the curd and whey was gently stirred for $10 \mathrm{~min}$ without added heat. The temperature was increased gradually from 31 to $33^{\circ} \mathrm{C}$ over 15 min and then from 33 to $38^{\circ} \mathrm{C}$ over an additional 15 min. The curd was continuously stirred at $38^{\circ} \mathrm{C}$ until the target whey draining $\mathrm{pH}$ of 6.45 was attained. The whey was drained and immediately pasteurized using a plate heat exchanger (with 3 sections: regeneration, heating, and cooling, model 080-S, AGC Engineering) at $72^{\circ} \mathrm{C}$ for $16 \mathrm{~s}$. The whey was cooled to $50^{\circ} \mathrm{C}$ at the exit of the pasteurizer and immediately processed with a cream separator (model 619, DeLaval Inc., Kansas, MO) to reduce the fat content. The fat content of the whey before separation was $0.23 \% \pm 0.01$ and after separation was $0.04 \% \pm 0.004$. The whey was mixed and sampled directly before and after cream separation. After separation, if the whey was not going to be bleached, it was cooled to $4^{\circ} \mathrm{C}$ with a plate heat exchanger and held overnight at $\leq 4^{\circ} \mathrm{C}$. If the whey was 
going to be bleached, it was heated with a plate heat exchanger to $66^{\circ} \mathrm{C}$ in a large stainless steel tank. Two different bleaches were used: BP at $50 \mathrm{mg} / \mathrm{kg}$ (Oxylite Type XX Benzoyl Peroxide $32 \%$ by weight, Nelson Jameson, Marshfield, WI) and HP at $500 \mathrm{mg} / \mathrm{kg}(35 \%$ HP, FCC grade, Columbus Chemical Industries Inc., Columbus, WI). The concentration of BP applied in this study represents a moderate concentration within the range governed by Good Manufacturing Procedures, but in excess of what is required for effective bleaching of liquid whey (Listiyani et al., 2012) to represent a worst-case scenario. Similarly, hydrogen peroxide concentration applied represents the legal limit allowed in the United States (US FDA, 2009). When bleaching with $\mathrm{BP}$, the powdered bleach was mixed with about 30 $\mathrm{kg}$ of whey using a high-shear mixer and added to the batch of whey. The whey was held for 30 min at $66^{\circ} \mathrm{C}$ with stirring and then cooled to $4^{\circ} \mathrm{C}$. When bleaching with HP, the HP was added to about $30 \mathrm{~kg}$ of whey, mixed with the remainder of the separated whey, and stirred for $30 \mathrm{~min}$ at $66^{\circ} \mathrm{C}$. The HP concentration in the reagent concentrate was tested before use with a hydrogen peroxide test strip by diluting the concentrate from $35 \%$ (wt/wt) to $10 \%$ (wt/wt) concentration. The $10 \%$ (wt/wt) concentration was verified with a $10 \%$ (wt/wt) HP test strip (Indigo Instruments, Niagara Falls, NY). If the HP concentration was lower than $10 \%$ (wt/wt), then the actual concentration was calculated and the amount of HP was adjusted to achieve an added level of $500 \mathrm{mg} / \mathrm{kg}$ in the cheese whey. After $30 \mathrm{~min}$, the whey was cooled with a plate heat exchanger to 49 to $52^{\circ} \mathrm{C}$, liquid catalase enzyme derived from Aspergillus niger (FoodPro CAT, Pd216626-2.0EN, Danisco, Madison, WI) was added at a concentration of $20 \mathrm{mg} / \mathrm{kg}$ of catalase in the whey, and then the whey was mixed for $10 \mathrm{~min}$. The whey was cooled to $4^{\circ} \mathrm{C}$ with a plate heat exchanger and held overnight at $4^{\circ} \mathrm{C}$ before spray drying.

\section{WPC Manufacture}

Approximately $700 \mathrm{~kg}$ of separated whey was heated to $50^{\circ} \mathrm{C}$ and processed with the UF system in batch recirculation mode using a polyethersulfone, spiralwound UF membrane (model 3838, GEA Niro Inc., Hudson, WI) with a nominal pore size of 10,000 Da. Before processing, the UF membrane was cleaned following the same procedure described in Evans et al. (2009). The water flux was typically about $54 \mathrm{~kg} / \mathrm{m}^{2}$ per hour at $50^{\circ} \mathrm{C}$. Whey was ultrafiltered for about $2 \mathrm{~h}$ to achieve a concentration factor of approximately $5 \times$. The process was stopped when the protein content of the retentate measured by infrared spectrophotometer (Lactoscope FTIR, Delta Instruments, Drachten, the
Netherlands) was $41 \%$ of protein expressed as a percentage of lactose plus fat plus protein in the retentate. The UF retentate was diluted with pasteurized reverse osmosis water at $50^{\circ} \mathrm{C}$ to bring the weight back to the original total weight of the starting whey for diafiltration. The membrane was not cleaned before proceeding to the diafiltration stage. The mixture was recirculated through the membrane for $5 \mathrm{~min}$ to ensure complete mixing. Then, the diluted UF retentate was underwent diafiltration to achieve a concentration factor of about $11.3 \times$. Diafiltration was continued until the protein content of the retentate measured by infrared spectrophotometer was 91.2 to $91.6 \%$ of protein as a percentage of lactose plus fat plus protein in the retentate. The total time of diafiltration was about $2 \mathrm{~h}$. At the end of processing, the retentate drained from the dead volume of the system was mixed with the retentate in the feed vat, mixed, and sampled. The final liquid retentate protein concentrate was weighed and cooled to $4^{\circ} \mathrm{C}$ and held overnight until spray drying the next day. After producing the $80 \%$ WPC liquid concentrate, the UF system was cleaned as described by Evans et al. (2009). The clean water flux after final cleaning was typically about $54 \mathrm{~kg} / \mathrm{m}^{2}$ per hour at $50^{\circ} \mathrm{C}$.

\section{Spray Drying}

The $80 \%$ WPC were spray-dried using a spray dryer (model 1, Niro Atomizer Inc., Columbia, MD). The feed material (about $40 \mathrm{~kg}$ ) was kept at or below $7^{\circ} \mathrm{C}$. The spray dryer was equipped with an FU11 atomizer rotating at 23,000 rpm and the feed rate was 16 $\mathrm{kg} / \mathrm{h}$. The inlet temperature was $200^{\circ} \mathrm{C}$ and the outlet temperature at the bottom of the spray dryer cone was $95^{\circ} \mathrm{C}$. The powder from the first $10 \mathrm{~min}$ of the run was discarded. Powder exited the bottom of the dryer cone, went through a cyclone to separate the powder from the hot air, and was collected. The powder in the collection vessel was about 30 to $35^{\circ} \mathrm{C}$. The dried product was collected, mixed, and packaged every $30 \mathrm{~min}$. The total time of the drying run was approximately $3.5 \mathrm{~h}$. The $80 \%$ WPC for sensory and functional property testing was packaged in polyethylene terephthalate (Mylar) zip-lock bags (Sorbent Systems, Los Angeles, CA) and shipped to North Carolina State University (Raleigh). Upon receipt, samples were sub-sampled and stored at $-80^{\circ} \mathrm{C}$ in black Whirlpak bags (ULINE, Pleasant Prairie WI).

\section{Chemical Analyses}

Milk for cheese making was analyzed using an infrared spectrophotometer (Lactoscope FTIR, Delta Instruments) for fat and true protein contents (Kayle- 
gian et al., 2006). The fat content of unseparated, separated whey, and liquid $80 \%$ WPC before drying was determined by ether extraction (AOAC, 2000; method 989.05; 33.2.26).

Fresh samples of the final liquid $80 \%$ WPC were analyzed for fat, TS, total N, and NPN content using ether extraction (AOAC, 2000; method 989.05; 33.2.26), forced-air oven drying (AOAC, 2000; method 990.20; 33.2.44), Kjeldahl (AOAC, 2000; method 991.20; 33.2.11), and Kjeldahl (AOAC, 2000; method 991.21; 33.2 .12 ), respectively. The $\mathrm{pH}$ of final liquid $80 \% \mathrm{WPC}$ was measured with an electrode (model HA 405, Mettler Toledo, Columbus, $\mathrm{OH}$ ) that was standardized at $\mathrm{pH} 6.97$ and 4.06 at $50^{\circ} \mathrm{C}$ and kept immersed in $3 \mathrm{M}$ $\mathrm{KCl}$ at $50^{\circ} \mathrm{C}$ between readings to keep its temperature equal to that of the buffers and samples.

The $80 \%$ WPC powders were reconstituted to $10 \%$ solids, and the liquids were analyzed for fat and total $\mathrm{N}$ by the methods indicated above. The $\mathrm{pH}$ was measured with an electrode (model Electrolyte 9823, Mettler Toledo) that was standardized at $\mathrm{pH} 7.01$ and 4.00 at $22^{\circ} \mathrm{C}$. The reconstituted samples were analyzed for TS content by forced-air oven drying (AOAC, 2000; method $990.20 ; 33.2 .44$ ) and the moisture content of the powder was calculated. Mineral analysis was determined by the North Carolina State University Analytical Services Laboratory (Raleigh) using a standard dry ash method with inductively coupled plasma optical emission spectroscopy (Lloyd et al., 2009).

\section{Color Analysis of Liquid and Spray-Dried WPC80}

The Hunter L (lightness), a (red-green), and b (yellow-blue) values for the fresh $80 \%$ WPC powders were determined in duplicate with a MacBeth Color-Eye spectrophotometer (model 2020, Kollmorgen Instruments Corp., Newburgh, NY) with Optiview software from the same company. The Hunter values were computed from the diffuse reflectance data in the 360 to $740 \mathrm{~nm}$ range, at 20-nm intervals, based on illuminant A. The measurements were done at 23 to $25^{\circ} \mathrm{C}$. Color measurements on the powders were done by packing the powder into a plastic dish that had a screw cap lid. The powders were also reconstituted to $10 \%$ (wt/vol) solids (as described above), and color measurements of these liquids were done using a 1-cm cuvette. The white reference color tile was placed behind the cuvette to reflect transmitted light back through the sample to the detector. This effectively doubled the path length of the cuvette and increased the sensitivity of the method to detect differences in color of the reconstituted powder solutions among treatments. Color was measured by reflectance through the bottom of the plastic dish.

\section{Extraction and Quantification of Norbixin}

Norbixin extraction and quantification from WPC80 was conducted using the method from Campbell et al. (2011a). Extractions were preformed under lights covered with premium full-spectrum F885 flat sheet filters (Ergomart, Dallas, TX) to minimize norbixin isomerization and degradation (Mercadante, 2008). Chloroform, ethanol, methanol, and water were obtained from EMD Chemicals Inc. (Gibbstown, NJ). Glacial acetic acid $(17.4 M)$ was obtained from Mallinckrodt Baker (Phillipsburgh, NJ). The WPC (1 g) was weighed into a 50-mL polypropylene centrifuge tube (Nalgene, Thermo Scientific, Rochester, NY). All extractions were conducted in triplicate. Following extraction and solidphase extraction column purification (Campbell et al., 2011a), the concentration of norbixin was determined spectrophotometrically using a UV-visible spectrophotometer (UV-1700 Pharmaspec, Shimadzu, Durham, $\mathrm{NC}$ ). A $0.7-\mathrm{mL}$ aliquot of each sample was measured in a 1-cm 28Q10 Spectrosil quartz cuvette (Starna Cells Inc., Atascadero, CA) and measured at $458 \mathrm{~nm}$, the maxima for norbixin (Croissant et al., 2009). A 5-point standard curve was created within the concentration range of $50 \mu \mathrm{g} / \mathrm{kg}$ to $10 \mathrm{mg} / \mathrm{kg}$ norbixin. Norbixin powder (45\% wt/wt, Chr. Hansen Inc.) was rehydrated in $2.5 \%$ potassium hydroxide (VWR International, Bridgeport, NJ) solution to make a $2,250 \mathrm{mg} / \mathrm{kg}$ solution and then diluted in methanol:glacial acetic acid [7:3 ( vol/vol)] to make a $112.5 \mathrm{mg} / \mathrm{kg}$ solution. Norbixin concentration was calculated by the total solids of the rehydrated WPC and correction for dilution during the extraction and solid-phase extraction processes and by an external standard curve. Measurements on the spectrophotometer were conducted in duplicate.

\section{Descriptive Sensory Analysis}

Sensory testing was conducted in compliance with North Carolina State University Institutional Review Board for Human Subjects approval. A trained sensory panel ( $\mathrm{n}=10,9$ females, 1 male, ages 22 to $50 \mathrm{yr}$ ) evaluated the flavor attributes of reconstituted WPC80 at $10 \%$ solids using a previously published lexicon for dried dairy ingredients (Drake et al., 2003, 2009; Wright et al., 2009; Listiyani et al., 2011). Each panelist had over $150 \mathrm{~h}$ of experience with descriptive analysis of whey and dried whey products using the Spectrum descriptive analysis method (Meilgaard et al., 1999; Drake and Civille, 2003). Reconstituted solutions of $10 \%$ solids (wt/vol) were prepared with no overhead lights to avoid exposure to light. Samples were pipetted into 60-mL soufflé cups, lidded, and labeled with a unique 
3-digit code. Samples were evaluated in duplicate by each panelist. Products were presented in a randomized order and scored using paper ballots or computerized ballots using Compusense 5 release 4.8 (Compusense Inc., Guelph, ON, Canada).

\section{Volatile Compound Extraction: Headspace Solid- Phase Microextraction GC-MS of WPC80 Powders}

Volatile compounds were extracted by headspace solid-phase microextraction and then separated and identified by GC-MS in triplicate using a modified method of Campbell et al. (2011a). Spray-dried powders were reconstituted at $10 \%$ (wt/vol) solids, with $10 \%$ (wt/ vol) $\mathrm{NaCl}$ (Fisher Scientific, Fairlawn, NJ). Five milliliters of sample with $5 \mu \mathrm{L}$ of 2-methy-3-heptanone (81 $\mathrm{mg} / \mathrm{kg}$ ) in ether (Sigma Aldrich., Milwaukee, WI) internal standard was added to 20-mL autosampler vials with steel screw tops containing silicone septa faced in Teflon (Microliter Analytical, Suwannee, FL). Samples were injected using a CombiPal autosampler (CTC Analytics, Zwingen, Switzerland) attached to an Agilent 6890N GC with 5973 inert MSD (Agilent Technologies Inc., Santa Clara, CA). Samples were maintained at $10^{\circ} \mathrm{C}$ before fiber exposure. Samples were equilibrated at $40^{\circ} \mathrm{C}$ for $25 \mathrm{~min}$ before $30 \mathrm{~min}$ fiber exposure of a 1-cm DVB/CAR/PDMS (divinylbenzene/carboxen/ polydimethylsiloxane) fiber at $31 \mathrm{~mm}$ with 4 -s pulsed agitation at $250 \mathrm{rpm}$. Fibers were injected for $5 \mathrm{~min}$ at a depth of $50 \mathrm{~mm}$.

The GC method used an initial temperature of $40^{\circ} \mathrm{C}$ for 3 min with a ramp rate of $10^{\circ} \mathrm{C} / \mathrm{min}$ to $90^{\circ} \mathrm{C}$, a ramp rate of $5^{\circ} \mathrm{C} / \mathrm{min}$ to $200^{\circ} \mathrm{C}$, held for $10 \mathrm{~min}$, a ramp rate of $20^{\circ} \mathrm{C} / \mathrm{min}$ to $250^{\circ} \mathrm{C}$, and held for $5 \mathrm{~min}$. The solid-phase microextraction fibers were introduced into the split/splitless injector at $250^{\circ} \mathrm{C}$. An Rtx-5ms column (Rtx-5ms $30 \mathrm{~m}$ length $\times 0.25 \mathrm{~mm}$ i.d. $\times 0.25$ $\mu \mathrm{m}$ film thickness; Restek, Bellefonte, PA) was used for all analyses, using helium as a carrier gas at a constant flow rate of $1 \mathrm{~mL} / \mathrm{min}$. Purge time was set at $1 \mathrm{~min}$. The MS transfer line was maintained at $250^{\circ} \mathrm{C}$ with the quadrupole at $150^{\circ} \mathrm{C}$ and source at $250^{\circ} \mathrm{C}$. Compounds were identified using the NIST 2005 library of spectra and comparison of spectra of authentic standards injected under identical conditions (NIST, 2005). Relative abundance for each compound was calculated using the calculated recovery and concentration of internal standard. Compounds of interest (dimethyl disulfide, hexanal, heptanal, 1-octen-3-one, 2-pentyl furan, octanal, nonanal, and decanal) were quantified using external standard calibration curves. These compounds were chosen because they showed significant differences
$(P<0.05)$ among the 6 treatments. Retention indices were calculated using an alkane series (Sigma-Aldrich; Van den Dool and Kratz, 1963).

Quantification of specific volatile compounds identified in samples was conducted using 5-point external standard curves ranging from $0.50 \mu \mathrm{g} / \mathrm{kg}$ to $2 \mathrm{mg} / \mathrm{kg}$ (ranges varied between these 2 extremes depending on the compound of interest), integrated to the internal standard (81 $\mathrm{mg} / \mathrm{kg}$ 2-methyl-3-heptanone). Fresh egg white protein from free-range eggs (organic, cagefree, antibiotic-free, no n-3 fatty acid additions) was purchased from a local grocery store (Whole Foods, Raleigh, NC) and used as the protein medium for the external standard curves. The egg whites were evaluated by headspace solid-phase microextraction and GC-MS to ensure they were free of target compounds. External standard curves were prepared by pipetting $4.0 \mathrm{~mL}$ of egg whites (approximately a 10\% protein solution, wt/vol) into $20-\mathrm{mL}$ autosampler vials with steel screw-top lids lined with silicone septa faced in Teflon with spiked amounts of target compounds and $10 \mu \mathrm{L}$ of internal standard; HPLC-grade water was used to bring the total solution volume to $5.0 \mathrm{~mL}$. Sodium chloride was added to the vials before addition of egg white protein so that the total solution was $10 \%$ (wt/vol) sodium chloride.

\section{Functional Properties}

Foam Generation. An Artisan KitchenAid mixer (KitchenAid, St. Joseph, MI) with a 4.5-quart stationary bowl and a rotating wire beater was used for foam formation. Solutions of protein (10\% wt/vol of protein) were rehydrated for $6 \mathrm{~h}$ at room temperature (20 to $24^{\circ} \mathrm{C}$ ) on a stir plate set to $200 \mathrm{rpm}$. Solutions were refrigerated overnight at $4^{\circ} \mathrm{C}$ and brought up to $25^{\circ} \mathrm{C}$. Solutions were then adjusted to $\mathrm{pH} 7 \mathrm{using} 1 \mathrm{~N} \mathrm{HCl}$ or $1 \mathrm{~N} \mathrm{NaOH}$ (VWR International). All solutions were prepared in triplicate. A $200-\mathrm{mL}$ sample of solution was whipped at speed 10 (beater rpm of 752) for $19 \mathrm{~min}$ and 36 s (Davis and Foegeding, 2007).

Yield Stress. Yield stress of the foam was measured using vane rheometry (Pernell et al., 2000; Davis and Foegeding, 2007). A Brookfield 25xLVTDV-ICP viscometer (Brookfield Engineering Laboratories Inc., Middleboro, MA) was used at a speed of $0.3 \mathrm{rpm}$. The vane used was $10 \mathrm{~mm}$ in diameter and $40 \mathrm{~mm}$ in length. Maximum torque response $\left(\mathrm{M}_{\mathrm{o}}\right)$ was recorded for each foam in triplicate. Torque measurements were used to calculate yield stress using the following formula published by Dzuy and Boger (1983, 1985) and Steffe (1996): 


$$
\tau_{o}=\frac{\mathrm{M}_{\mathrm{o}}}{[(\mathrm{h} / \mathrm{d})+(1 / 6)]\left[\left(\pi \mathrm{d}^{3}\right) / 2\right]},
$$

where $\tau_{o}$ is yield stress, and $\mathrm{h}$ and $\mathrm{d}$ are the height and diameter of the vane, respectively. Torque was measured in triplicate per solution.

Overrun. Overrun measurements were conducted after yield stress. Foam was removed from the bowl using a rubber spatula in a circular pattern and filling a weighing dish $(100 \mathrm{~mL})$ in triplicate. The mean value was used to calculate overrun and air phase fraction using the following equations:

$$
\begin{gathered}
\text { Overrun }= \\
\frac{(\text { wt of } 100 \mathrm{~mL} \text { of solution })-(\text { wt of } 100 \mathrm{~mL} \text { of foam })}{\text { wt of } 100 \mathrm{~mL} \text { of foam }} \\
\text { Air phase fraction }(\phi)=\frac{\% \text { overrun }}{(\% \text { overrun }+100)} .
\end{gathered}
$$

All treatments were measured in triplicate (Dickinson, 1999; Wilde, 2000; Davis and Foegeding, 2007).

Stability. Foam drainage was measured after overrun using the methods of Phillips et al. (1990) and Luck et al. (2001). Foam stability was measured by the time it took for half of the prefoam mass to drain through a hole in a whipping bowl. The mass of foam removed during the overrun measurements was subtracted when calculating the prefoam mass. The starting time for these measurements was taken immediately after foam formation (Davis and Foegeding, 2007).

Solubility. Solutions of $10 \%$ protein (wt/vol) were made by rehydrating the WPC 80 to $80 \%$ of the total volume desired (target final volume for this experiment was $100 \mathrm{~mL}$ for each subsequent treatment), for $6 \mathrm{~h}$ at room temperature $\left(20\right.$ to $\left.24^{\circ} \mathrm{C}\right)$ on a stir plate set to $200 \mathrm{rpm}$ (Campbell et al., 2011a). Solutions were refrigerated overnight at $4^{\circ} \mathrm{C}$ and brought up to $25^{\circ} \mathrm{C}$. Solutions were then adjusted using $1 \mathrm{~N} \mathrm{HCl}$ or $1 \mathrm{~N}$ $\mathrm{NaOH}$ to $\mathrm{pH} 3,4,5,6$, or 7 and brought to a total volume of $100 \mathrm{~mL}$ with deionized water, resulting in $10 \%$ (wt/vol) protein solutions. Turbidity and solubility using the micro bicinchoninic acid (micro-BCA) assay were measured on the uncentrifuged solutions. Solutions were then centrifuged at $16,500 \times g$ for 10 min using a model RC5B centrifuge (Thermo Scientific) and the supernatants were measured for solubility. Solubility measurements were recorded before and after centrifugation.

Solubility was measured by the micro-BCA assay using a kit from Thermo Fisher Scientific/Pierce
(Rockford, IL). Protein solutions before and after centrifugation were diluted 1:100 in deionized water. Solutions were added to a working reagent in a ratio of 1:8 and pipetted in triplicate into a 96 -well plastic plate. Deionized water with working solution was used as a reference blank. The plate was put on a shaker for $30 \mathrm{~s}$ and incubated at $37^{\circ} \mathrm{C}$ for $30 \mathrm{~min}$. The plate was brought to room temperature and read on a Tecan Safire plate reader spectrophotometer at wavelength $562 \mathrm{~nm}$ (Tecan, Durham, NC). Analysis was performed in quadruplicate. Solubility was calculated using the following equation (where Abs = absorbance):

$$
\begin{gathered}
\text { Protein solubility }=100-\left\{\left[\left(\mathrm{Abs}_{\text {before }}-\mathrm{Abs}_{\mathrm{after}}\right) /\right.\right. \\
\left.\left.\mathrm{Abs}_{\text {before }}\right] \times 100\right\} .
\end{gathered}
$$

Turbidity was used as a second measurement of solubility. Turbidity was measured using a Hach 2100AN Turbidimeter (Loveland, CO) that used a tungstenfilament lamp as a light source focused by a lens and measured transmitted light, back scattering, forward scattering, and $90^{\circ}$ angle scattering light. Samples were pipetted into glass cuvettes and measured in quadruplicate. Turbidity was calculated using the following equation:

$$
\begin{gathered}
\% \text { Turbidity }=\left\{\left[\left(\text { Turbidity }_{\text {before }}-\text { Turbidity }_{\text {after }}\right) /\right.\right. \\
\text { Turbidity } \left.\left.\left._{\text {before }}\right)\right] \times 100\right\} .
\end{gathered}
$$

Heat Stability. Heat stability was measured using methods described by Campbell et al. (2011a) with modifications. Solutions were prepared the same as for solubility with the exception that all solutions were made at 5\% (wt/vol) and 10\% (wt/vol) protein. Solutions were increased to $\mathrm{pH} 7$ using $1 \mathrm{~N} \mathrm{NaOH}$ and heated in a water bath at $90^{\circ} \mathrm{C}$ for $0,10,20$, or $30 \mathrm{~min}$. Samples were immediately placed in an ice bath until the sample was back to $25^{\circ} \mathrm{C}$. Turbidity and micro-BCA measurements of solubility were taken before and after centrifugation and calculated as described previously. The supernatant was then collected and brought to $\mathrm{pH} 4.6$ using $1 \mathrm{~N} \mathrm{HCl}$. Turbidity and solubility were measured on the $\mathrm{pH} 4.6$ supernatant before and after centrifugation. All solutions were measured in quadruplicate.

\section{Statistical Analyses}

Data were analyzed by ANOVA using the Proc GLM procedures of SAS (version 8.02, 1999-2001, SAS Institute Inc., Cary, NC) to determine if significant differences existed in color, composition, chemical com- 
Table 1. Mean ( $\mathrm{n}=3$ ) composition (\% by weight) of the liquid $80 \%$ whey protein concentrate (WPC) with and without annatto color added to the milk followed by no bleaching, bleaching with benzoyl peroxide (BP; $50 \mathrm{mg} / \mathrm{kg}$ ), or bleaching with hydrogen peroxide (HP; $500 \mathrm{mg} / \mathrm{kg}$ ) before spray drying ${ }^{1,2}$

\begin{tabular}{|c|c|c|c|c|c|c|}
\hline \multirow[b]{2}{*}{ Treatment } & \multicolumn{3}{|c|}{ Unseparated whey } & \multicolumn{3}{|c|}{ Separated whey } \\
\hline & Total solids & Fat & $\mathrm{CP}$ & Total solids & Fat & $\mathrm{CP}$ \\
\hline No color $+\mathrm{HP}$ & 6.90 & 0.23 & 0.93 & 6.73 & 0.04 & 0.91 \\
\hline Annatto & 6.79 & 0.22 & 0.92 & 6.71 & 0.04 & 0.92 \\
\hline Annatto + BP & 6.87 & 0.23 & 0.92 & 6.72 & 0.04 & 0.92 \\
\hline SE & 0.039 & 0.005 & 0.01 & 0.012 & 0.002 & 0.009 \\
\hline
\end{tabular}

${ }^{1}$ No differences in means within the same column were detected $(P>0.05)$.

${ }^{2} \mathrm{CP}=$ total $\mathrm{N} \times 6.38$.

position, descriptive analysis, and instrumental data due to annatto or bleaching treatment. Fisher's least significant difference was conducted as a post hoc test. Principal component analysis was applied to the correlation matrix of sensory and volatile component data to visualize how bleaching agent differentiated WPC80 samples based upon sensory attributes or volatile components.

\section{RESULTS}

\section{Mineral and Composition}

For all 6 treatments, no differences were detected $(P$ $>0.05$ ) in the unseparated whey and separated whey mean values for TS, fat, or CP (Table 1). Compositional differences among treatments were also not detected in spray-dried powders $(P<0.05$; Table 2$)$. Both WPC80 HP treatments had lower iron compared with other WPC80 $(P<0.05$; Table 3$)$. No other consistent trends were observed for the minerals among treatments.
Color

Bleaching whey with added annatto with BP or HP increased $(P<0.05)$ the L-values (whiteness) of powders (Table 4 ). The a-values (negative values green, positive values red) of the unbleached liquid whey and powder with added annatto had slightly more $(P<$ $0.05)$ red character than those with no added annatto. The redness of the liquids and powders with added annatto was reduced $(P<0.05)$ by bleaching, with the redness of the powder reduced more by BP bleaching than by HP bleaching. It is interesting to note that bleaching of the whey without added annatto made the liquid whey more green, with the effect $(P<0.05)$ being greater for HP than for BP. The HP reduced the redness of the powder with no annatto added, but the magnitude of the a-value decrease with the HP bleaching was not as large as that observed for the liquid whey. The b-values (negative value blue, positive values yellow) for annatto-colored unbleached liquids and powders were more positive $(P<0.05)$ than those

Table 2. Mean ( $\mathrm{n}=3$ ) composition (\% by weight) of spray-dried $80 \%$ whey protein concentrate with and without annatto color added to the milk followed by no bleaching, bleaching with benzoyl peroxide (BP; 50 $\mathrm{mg} / \mathrm{kg}$ ), or bleaching with hydrogen peroxide (HP; $500 \mathrm{mg} / \mathrm{kg}$ ) calculated on a dry and wet basis ${ }^{1,2}$

\begin{tabular}{|c|c|c|c|c|c|}
\hline \multirow[b]{2}{*}{ Treatment } & \multirow[b]{2}{*}{ Moisture } & \multicolumn{2}{|c|}{ Dry basis } & \multicolumn{2}{|c|}{ Wet basis } \\
\hline & & Fat & $\mathrm{CP}$ & Fat & $\mathrm{CP}$ \\
\hline No color & 3.64 & 4.57 & 80.72 & 4.40 & 77.77 \\
\hline No color $+\mathrm{BP}$ & 2.80 & 4.54 & 80.98 & 4.41 & 78.68 \\
\hline No color $+\mathrm{HP}$ & 3.23 & 4.78 & 81.21 & 4.63 & 78.66 \\
\hline Annatto & 3.89 & 4.84 & 81.25 & 4.65 & 78.06 \\
\hline Annatto $+\mathrm{BP}$ & 2.64 & 4.65 & 80.15 & 4.52 & 78.02 \\
\hline Annatto $+\mathrm{HP}$ & 2.76 & 4.61 & 80.31 & 4.48 & 78.08 \\
\hline $\mathrm{R}^{2}$ & 0.76 & 0.64 & 0.88 & 0.64 & 0.88 \\
\hline $\mathrm{SE}$ & 0.41 & 0.08 & 0.40 & 0.07 & 0.37 \\
\hline
\end{tabular}


Table 3. Mean $(\mathrm{n}=3)$ mineral composition of spray-dried $80 \%$ whey protein concentrate with and without annatto color added to the milk followed by no bleaching, bleaching with benzoyl peroxide (BP; $50 \mathrm{mg} / \mathrm{kg}$ ), or bleaching with hydrogen peroxide (HP; $500 \mathrm{mg} / \mathrm{kg}$ ) calculated on a dry basis

\begin{tabular}{|c|c|c|c|c|c|c|c|}
\hline Treatment & \multicolumn{7}{|c|}{ Mineral composition (wt \%) } \\
\hline No color & $0.356^{\mathrm{c}}$ & $0.564^{\mathrm{b}}$ & $0.516^{\mathrm{a}}$ & $0.062^{\mathrm{a}}$ & $10.8^{\mathrm{a}}$ & $0.256^{\mathrm{b}}$ & $1.09^{\mathrm{ab}}$ \\
\hline No color HP & $0.368^{\mathrm{abc}}$ & $0.577^{\mathrm{ab}}$ & $0.505^{\mathrm{a}}$ & $0.060^{\mathrm{a}}$ & $6.45^{\mathrm{b}}$ & $0.303^{\mathrm{a}}$ & $1.09^{\mathrm{ab}}$ \\
\hline Annatto & $0.364^{\mathrm{abc}}$ & $0.546^{\mathrm{b}}$ & $0.518^{\mathrm{a}}$ & $0.063^{\mathrm{a}}$ & $11.0^{\mathrm{a}}$ & $0.274^{\mathrm{ab}}$ & $1.11^{\mathrm{a}}$ \\
\hline Annatto BP & $0.381^{\mathrm{a}}$ & $0.529^{b}$ & $0.538^{\mathrm{a}}$ & $0.060^{\mathrm{a}}$ & $9.63^{\mathrm{a}}$ & $0.295^{\mathrm{a}}$ & $1.10^{\mathrm{ab}}$ \\
\hline SE & 0.004 & 0.021 & 0.008 & 0.001 & 0.32 & 65.9 & 0.006 \\
\hline
\end{tabular}

${ }^{\mathrm{a}-c}$ Means in the same column not sharing a common superscript are different $(P<0.05)$.

for uncolored whey, as expected. Both the HP and BP treatments of the whey with annatto added were lower than annatto with no bleach for b-values for both the liquid and powder $(P<0.05)$. However, the BP with annatto color had lower b-values in liquid and powder compared with HP $(P<0.05)$, indicating that BP, under the bleaching conditions used in the study, was a more effective bleaching agent than HP. Bleaching with $\mathrm{BP}$ reduced the b-value of the liquid whey and whey powder to values that were not different $(P>$ 0.05 ) from those of the liquid and powdered whey with no annatto added. The bleaching reactivity of HP is not limited to norbixin as demonstrated by the fact that the HP bleaching reduced $(P<0.05)$ the b-value contributed by the naturally occurring pigments in the liquid whey with no added annatto compared with BP and no-bleach treatments (Table 4). The decrease in b-value of the HP-bleached uncolored whey was consistent with the fact that HP bleaching increased $(P<$ $0.05)$ the whiteness.

\section{Annatto Extraction}

Both the BP and the HP treatments reduced norbixin concentration $(P<0.05$; Table 5$)$. The norbixin extraction in WPC80 with or without annatto bleached with BP was not different from control WPC with no added annatto (results not shown). Hydrogen peroxide reduced norbixin $44 \%$ compared with the total norbixin concentration of the no-bleach annatto control; BP reduced norbixin $92 \%$ compared with the total norbixin concentration of the no-bleach annatto control.

\section{Sensory Analysis}

Descriptive analysis of rehydrated WPC80 differentiated the samples based upon treatment (Table 6, Figure 1). The HP-bleached samples were higher in cardboard and fatty flavors and had lower intensities of cooked/ milky and sweet aromatic flavors compared with the $\mathrm{BP}$ and the no-bleach samples $(P<0.05)$. The colored

Table 4. Mean $(\mathrm{n}=3)$ color (L-, a-, and b-values; lightness, redness, and yellowness, respectively) of liquid $(10 \% \mathrm{wt} /$ vol powders) and spray-dried $80 \%$ whey protein concentrate with and without annatto color added to the milk followed by no bleaching, bleaching with benzoyl peroxide (BP; $50 \mathrm{mg} / \mathrm{kg}$ ), or bleaching with hydrogen peroxide (HP; $500 \mathrm{mg} / \mathrm{kg}$ )

\begin{tabular}{|c|c|c|c|c|c|}
\hline \multirow[b]{2}{*}{ Treatment } & \multirow{2}{*}{$\frac{\text { L-value }}{\text { Powder }}$} & \multicolumn{2}{|c|}{ a-value } & \multicolumn{2}{|c|}{ b-value } \\
\hline & & Liquid & Powder & Liquid & Powder \\
\hline No color & $88.08^{c}$ & $-0.82^{\mathrm{b}}$ & $1.75^{\mathrm{c}}$ & $4.88^{\mathrm{c}}$ & $7.76^{\mathrm{c}}$ \\
\hline No color $+\mathrm{BP}$ & $88.59^{\mathrm{c}}$ & $-1.83^{\mathrm{c}}$ & $1.51^{\mathrm{c}}$ & $4.06^{\mathrm{cd}}$ & $7.22^{\text {cd }}$ \\
\hline No color $+\mathrm{HP}$ & $91.19^{\mathrm{a}}$ & $-4.18^{\mathrm{d}}$ & $0.53^{\mathrm{d}}$ & $0.27^{\mathrm{e}}$ & $6.39^{\mathrm{df}}$ \\
\hline Annatto & $86.74^{\mathrm{d}}$ & $1.45^{\mathrm{a}}$ & $3.59^{\mathrm{a}}$ & $14.39^{\mathrm{a}}$ & $15.33^{\mathrm{a}}$ \\
\hline Annatto $+\mathrm{BP}$ & $88.16^{\mathrm{c}}$ & $-1.55^{\mathrm{c}}$ & $1.63^{\mathrm{c}}$ & $5.82^{\mathrm{c}}$ & $8.54^{\mathrm{c}}$ \\
\hline Annatto $+\mathrm{HP}$ & $90.13^{\mathrm{b}}$ & $-1.72^{\mathrm{c}}$ & $2.45^{\mathrm{b}}$ & $10.86^{\mathrm{b}}$ & $12.82^{\mathrm{b}}$ \\
\hline $\mathrm{R}^{2}$ & 0.98 & 0.99 & 0.99 & 0.98 & 0.98 \\
\hline SE & 0.17 & 0.13 & 0.09 & 0.55 & 0.35 \\
\hline
\end{tabular}

${ }^{\mathrm{a}-\mathrm{f}}$ Means in the same column not sharing a common superscript are different $(P<0.05)$. 
Table 5. Mean $(\mathrm{n}=3)$ norbixin concentration $(\mathrm{mg}$ of norbixin $/ \mathrm{kg}$ of total solids) from $80 \%$ whey protein concentrate with and without annatto color added to the milk followed by no bleaching, bleaching with benzoyl peroxide (BP; $50 \mathrm{mg} / \mathrm{kg}$ ), or bleaching with hydrogen peroxide (HP; $500 \mathrm{mg} / \mathrm{kg}$ )

\begin{tabular}{lc}
\hline Treatment & Norbixin \\
\hline No color & $0.66^{\mathrm{d}}$ \\
No color BP & $0.55^{\mathrm{d}}$ \\
No color HP & $0.92^{\mathrm{cd}}$ \\
Annatto & $18.90^{\mathrm{a}}$ \\
Annatto BP & $1.45^{\mathrm{cd}}$ \\
Annatto HP & $10.63^{\mathrm{b}}$ \\
$\mathrm{R}^{2}$ & 0.98 \\
$\mathrm{SE}$ & 0.24 \\
\hline
\end{tabular}

${ }^{\mathrm{a}-\mathrm{d}}$ Means in the same column not sharing a common superscript are different $(P<0.05)$.

no-bleach WPC80 were lower in cardboard flavor than the uncolored no-bleach WPC80 $(P<0.05)$. This result may be due to an antioxidant effect of the added annatto. Campbell et al. (2011a) documented lower lipid oxidation products in colored WPC62 compared with uncolored WPC62, although sensory differences were not documented.

\section{Volatile Component Analysis}

The WPC80 with and without annatto bleached with HP was characterized by higher $(P<0.05)$ concentrations of hexanal, heptanal, octanal, nonanal, decanal, dimethyl disulfide, and 1-octen-3-one compared with no bleach and BP-bleached WPC80 with and without annatto (Table 7, Figure 1). All of these compounds have been previously identified in whey and are associated with lipid oxidation or protein degradation products (Wright et al., 2006; Croissant et al., 2009; Evans et al., 2010; Whitson et al., 2010; Listiyani et al., 2011). Both the BP with and without color WPC80 were significantly higher in 2-pentyl furan than the HP and control treatments $(P<0.05)$.

\section{Functionality}

None of the treatments foamed; therefore, yield stress, overrun, and stability could not be measured. Solubility by $\mathrm{pH}$ with no heat treatment was not different among treatments within a specific $\mathrm{pH}$ value $(P>$ 0.05; results not shown). Solubility results at selected $\mathrm{pH}$ with varying times of heating represented as heat stability indicated that both colored and uncolored HP WPC 80 at $10 \%$ (wt/vol) protein were more soluble $(P$ $<0.05$ ) after $10 \mathrm{~min}$ at $90^{\circ} \mathrm{C}$ than colored or uncolored $\mathrm{BP}$ or unbleached WPC at $\mathrm{pH} 7$ and $\mathrm{pH} 4.6$ (Figures 2 and 3). Turbidity measurements showed similar trends in protein solubility and micro-BCA measurements at $\mathrm{pH} 7$ and $\mathrm{pH} 4.6$ (results not shown). No differences in heat stability were observed at $5 \%(\mathrm{wt} / \mathrm{vol})$ protein at $\mathrm{pH} 7$ and $\mathrm{pH} 4.6(P>0.05$; results not shown). All treatments, including HP treatments, gelled after 20 and $30 \mathrm{~min}$ of heating at $90^{\circ} \mathrm{C}$; therefore, turbidity and micro-BCA measurements were not performed on these samples.

\section{DISCUSSION}

\section{Bleaching Efficacy}

Norbixin concentration (Table 5) as well as b-value measurements (Table 4) indicated that BP was a better bleaching agent for colored whey than HP. Benzoyl peroxide degraded $92 \%$ of the norbixin in colored WPC80 compared with only $44 \%$ degradation by HP. Listiyani et al. (2011) reported that WPC34 bleached with 50 $\mathrm{mg} / \mathrm{kg}$ of BP had less measured norbixin than WPC34 bleached with $500 \mathrm{mg} / \mathrm{kg}$ of HP. Higher b-values were

Table 6. Mean ( $\mathrm{n}=3$ replicates with 10 panelists) sensory attributes ${ }^{1}$ of $80 \%$ whey protein concentrate with and without annatto color added to the milk followed by no bleaching, bleaching with benzoyl peroxide (BP; $50 \mathrm{mg} / \mathrm{kg}$ ), or bleaching with hydrogen peroxide (HP; $500 \mathrm{mg} / \mathrm{kg})^{2}$

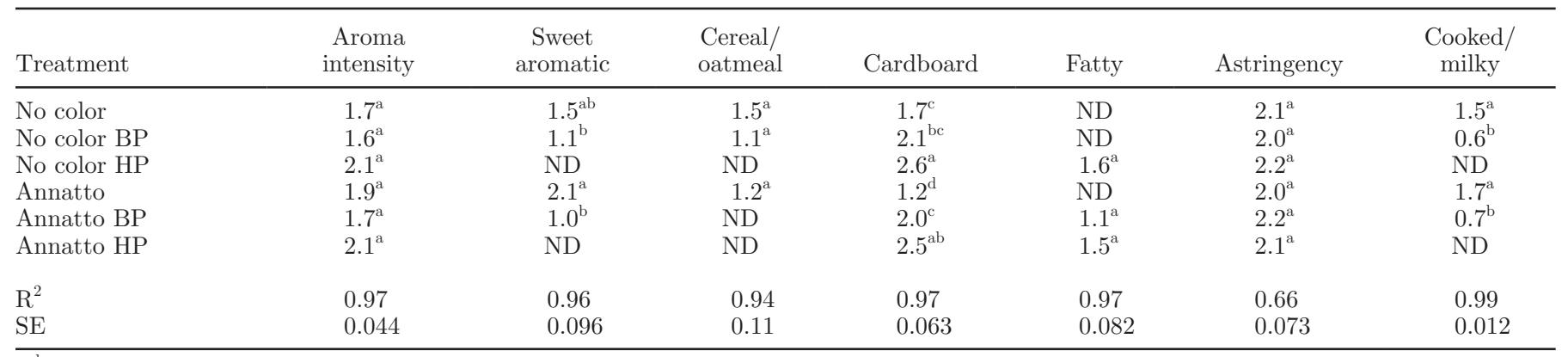

\footnotetext{
${ }^{\mathrm{a}-\mathrm{d}}$ Means in the same column not sharing a common superscript are different $(P<0.05)$.

${ }^{1}$ Intensities were scored on a 0 to 15 universal scale, where $0=$ none and $15=$ very high intensity (Meilgaard et al., 1999). Dried whey ingredient intensities usually fall between 0 and 4 on this scale (Drake et al., 2003; Wright et al., 2009).

${ }^{2}$ Attributes not listed were not detected (ND).
} 


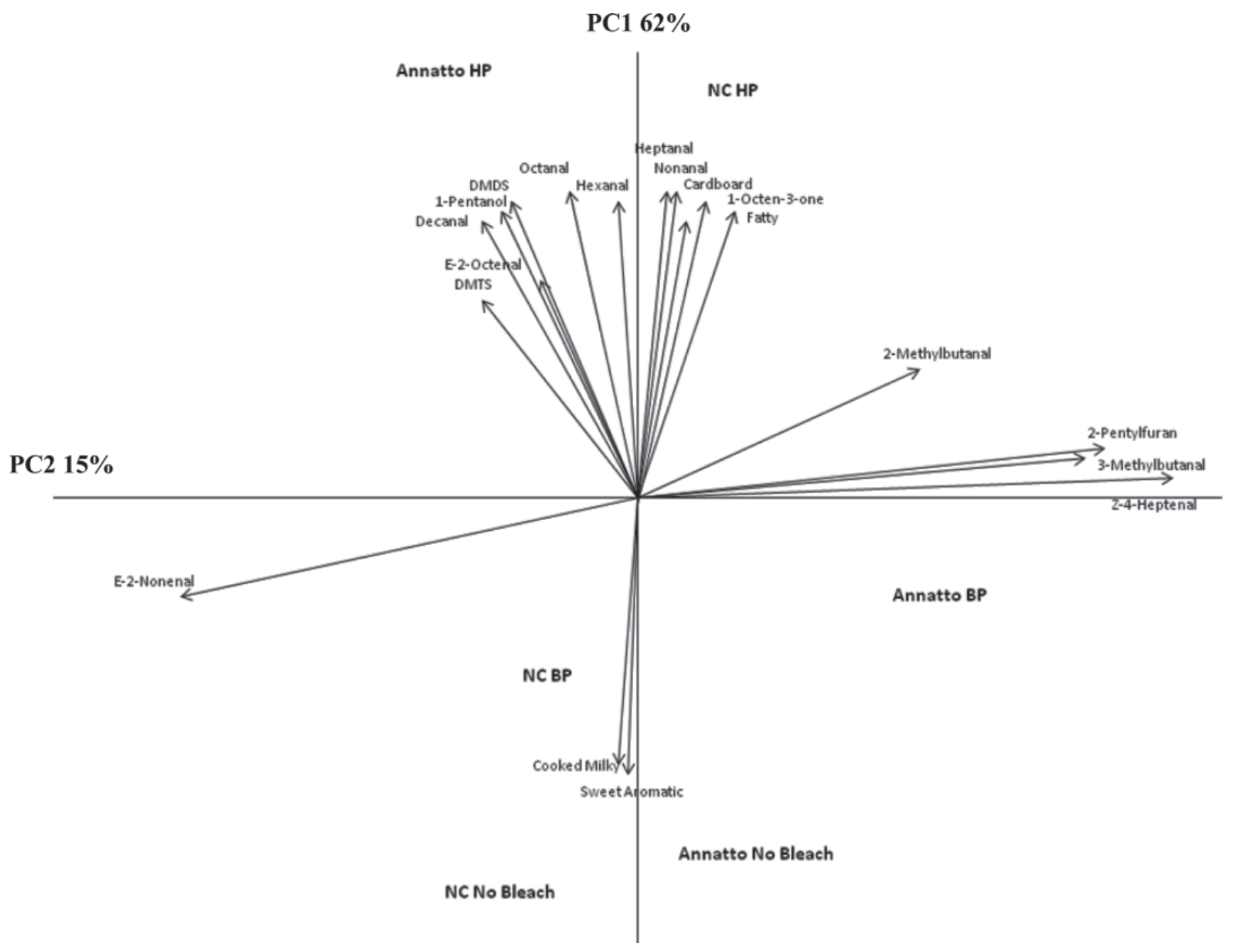

Figure 1. Principal component biplot of sensory attributes and selected lipid oxidation volatile components of $80 \%$ whey protein concentrate (WPC80) with and without annatto color added to the milk followed by no bleaching, bleaching with benzoyl peroxide (BP; $50 \mathrm{mg} / \mathrm{kg}$ ), or bleaching with hydrogen peroxide (HP; $500 \mathrm{mg} / \mathrm{kg}$ ).

also noted for colored HP WPC34 compared with colored BP WPC34. The b-value is associated with the blue to yellow spectrum, where a more positive b-value is more closely associated with yellow and a negative b-value is more closely associated with blue. The bvalues of HP-bleached colored WPC80 for liquid and powder were higher $(P<0.05)$ than those of the BPbleached colored WPC80. This result suggests that the colored HP-bleached WPC80 were more yellow than the colored BP-bleached WPC80. The L-values for the colored and uncolored HP samples for powder were higher than those for colored and uncolored BP and no bleach treatments. This result signifies that the HP created a brighter colored whey product compared with BP bleaching but not a less-yellow product. Bleach- ing is the chemical degradation of molecular moieties responsible for absorbing visible electromagnetic radiation, resulting in an increase in the total reflectance of the substrate, making it appear brighter (Dannacher, 2006). The bleaching mechanism for HP might be different from that of BP; namely, the HP attacks the norbixin pigment but also attacks other conjugated double bonds of compounds in the whey, affecting the brightness of the product, whereas the BP mechanism of bleaching appears focused on the norbixin pigment. This is supported by the low b-value of the HPbleached liquid whey when no annatto is added (Table 4). Croissant et al. (2009) reported that the L-value for HP-bleached WPC70 powder was higher than that for BP-bleached WPC70; the b-value for the BP WPC70 


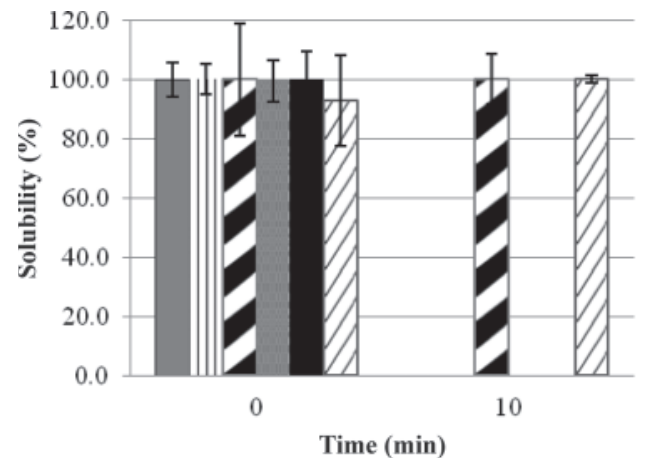

Figure 2. Percentage solubility of $80 \%$ whey protein concentrate (WPC80) at $\mathrm{pH} 7$ and 10\% (wt/vol) protein heated for $0,10,20$, and 30 min at $90^{\circ} \mathrm{C}$. The WPC were manufactured with and without annatto color added to the milk followed by no bleaching, bleaching with benzoyl peroxide (BP; $50 \mathrm{mg} / \mathrm{kg}$ ), or bleaching with hydrogen peroxide (HP; $500 \mathrm{mg} / \mathrm{kg}$ ). Solutions not represented at $10 \mathrm{~min}$ of heating at $90^{\circ} \mathrm{C}$ gelled and therefore could not be measured. All solutions gelled at 20 and $30 \mathrm{~min}$ of heating at $90^{\circ} \mathrm{C}$ and therefore are not represented on this figure.

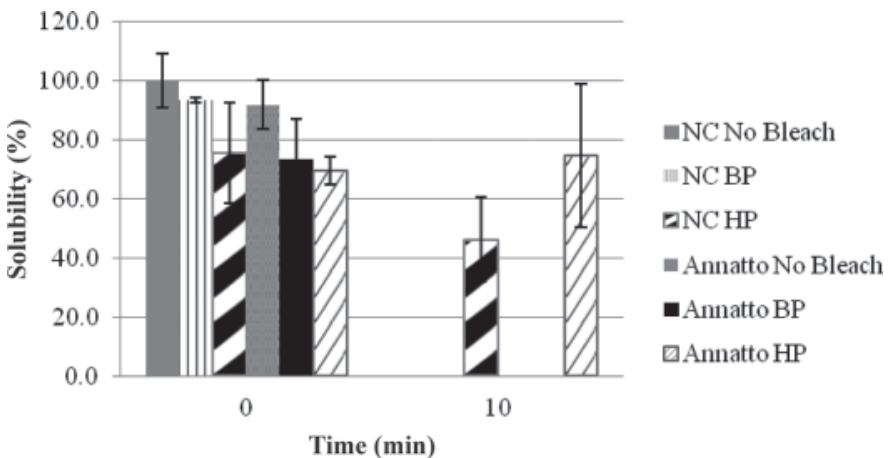

Figure 3. Percentage solubility of $80 \%$ whey protein concentrate (WPC 80 ) at $\mathrm{pH} 4.6$ and 10\% (wt/vol) protein heated for $0,10,20$, and $30 \mathrm{~min}$ at $90^{\circ} \mathrm{C}$. The WPC were manufactured with and without annatto color added to the milk followed by no bleaching, bleaching with benzoyl peroxide (BP; $50 \mathrm{mg} / \mathrm{kg}$ ), or bleaching with hydrogen peroxide (HP; $500 \mathrm{mg} / \mathrm{kg}$ ). Solutions not represented at $10 \mathrm{~min}$ of heating at $90^{\circ} \mathrm{C}$ gelled and therefore could not be measured. All solutions gelled at 20 and $30 \mathrm{~min}$ of heating at $90^{\circ} \mathrm{C}$ and therefore are not represented on this figure.

Table 7. Mean $(\mathrm{n}=3)$ concentrations of selected volatile compounds $(\mu \mathrm{g} / \mathrm{L})$ of spray-dried $80 \%$ whey protein concentrate with and without annatto color added to the milk followed by no bleaching, bleaching with benzoyl peroxide (BP; $50 \mathrm{mg} / \mathrm{kg}$ ), or bleaching with hydrogen peroxide (HP; $500 \mathrm{mg} / \mathrm{kg}$ ) isolated using solid-phase microextraction

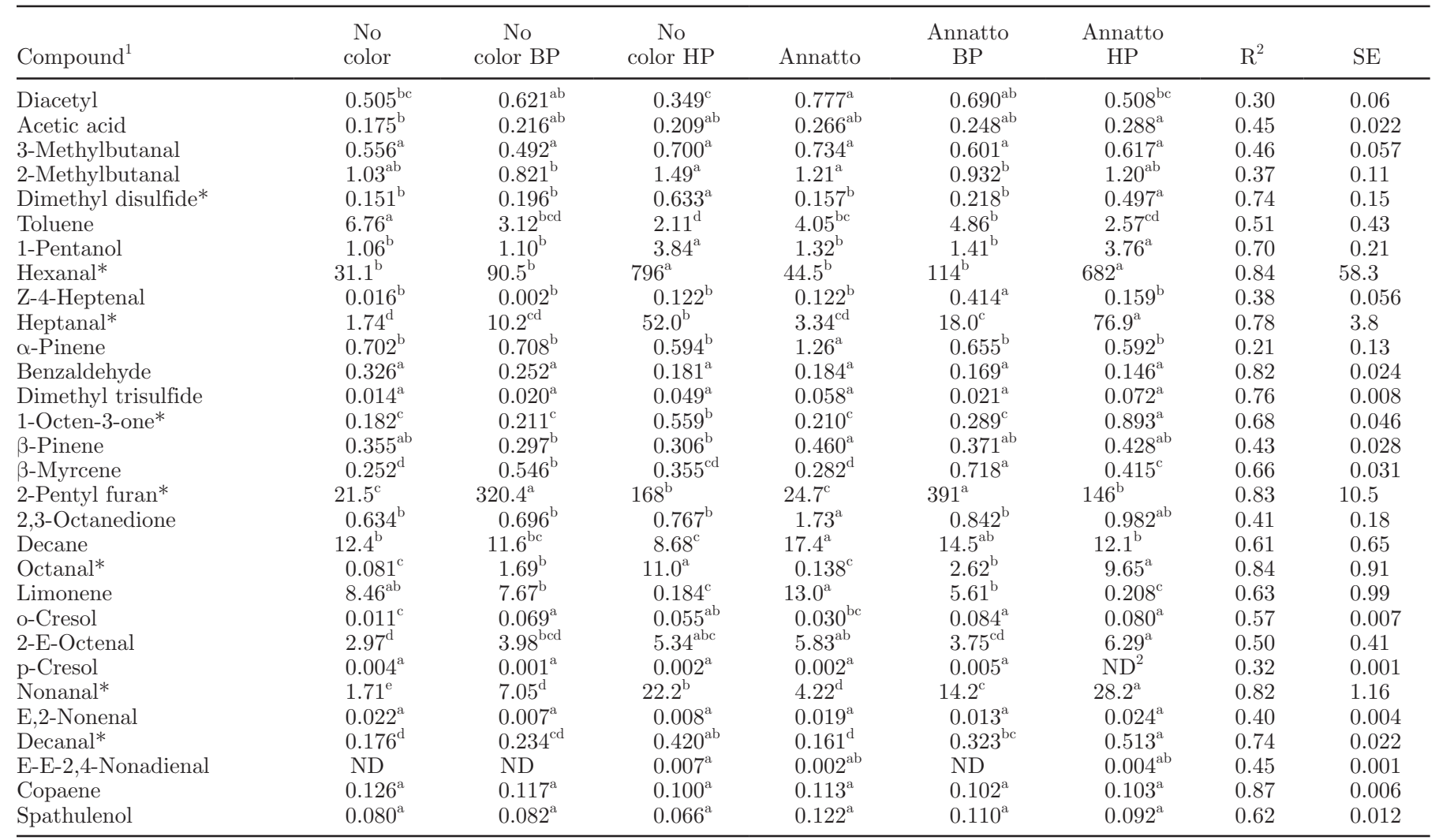

${ }^{\mathrm{a}-\mathrm{e}}$ Means in same row not sharing a common superscript are different $(P<0.05)$.

${ }^{1}$ Compounds with an asterisk $(*)$ are integrated to a 5-point external standard curve. All $\mathrm{R}^{2}$ values are greater than 0.94 .

${ }^{2} \mathrm{ND}=$ not detected. 
was lower than the HP WPC70. Listiyani et al. (2011) reported no differences in the L- or b-values for HPbleached and BP-bleached WPC34.

\section{Sensory and Volatile Component Analysis}

The WPC80 from HP- and BP-bleached wheys were distinct by sensory and volatile compound analysis. The HP treatments were higher in lipid oxidation and protein degradation compounds, as determined by volatile and sensory analyses, compared with BP or control unbleached WPC. The HP WPC80 were described as cardboard and fatty, both of which are attributed to lipid oxidation and protein degradation compounds (Tomaino et. al., 2004; Wright et al., 2009; Whitson et al., 2010). Whitson et al. (2010) attributed cardboard flavor to pentanal, heptanal, nonanal, 1-octen-3-one, and dimethyl trisulfide. The HP treatments had the highest concentrations of heptanal, nonanal, and 1-octen-3-one (Table 7). Dimethyl trisulfide (DMTS) was identified in all samples but was not significantly higher for HP samples; pentanal was not detected in WPC80. The most abundant volatile in the HP WPC 80 was hexanal; it is an indicator of lipid oxidation and can be formed by multiple pathways (Frankel, 2005). The BP WPC80 also had hexanal and other key lipid oxidation and protein degradation volatiles, but concentrations were not as high as those in HP WPC. Bleaching of whey with BP appears to favor the formation of 2 -pentyl furan. The large production of 2 very different quantities of compounds suggests that (1) the 2 bleaching agents oxidize free fatty acids through similar pathways but the reaction rate of HP is much higher than that of $\mathrm{BP}$, or (2) that the 2 bleaching agents oxidize free fatty acids through different pathways to end up with different concentrations of lipid oxidation products. Croissant et al. (2009) reported higher concentrations of hexanal, DMTS, heptanal, and octanal in WPC70 from HP-bleached whey. Listiyani et al. (2011) reported a higher concentration of octanal in WPC34 from HP-bleached whey. Both Croissant et al. (2009) and Listiyani et al. (2011) reported the same key lipid oxidation and protein degradation compounds in WPC from HP- and BP-bleached whey as identified in this study. Dimethyl disulfide and DMTS are formed from protein degradation of sulfur-containing amino acids (Wright et al., 2006).

Oleic and linoleic acids are two of the main unsaturated free fatty acids that form lipid oxidation products in whey. Milk fat is composed of approximately $25 \%$ oleic acid and $2 \%$ linoleic acid; however, the phospholipid component of the milk fat globule membrane is $6 \%$ linoleic acid (Frankel, 2005) and this fraction is amplified in whey products. When auto-oxidized, ole- ate forms 8-, 9-, 10-, and 11-hydroperoxides, which are further cleaved on the ester side to produce heptanal, octanal, nonanal, and decanal aldehydes, respectively. As these 4 aldehydes were significantly higher in HPbleached treatments compared with $\mathrm{BP}$ or control WPC, this is one possible mechanism for their formation. Hexanal can be produced through the cleavage of the 12-hydroperoxide formed from the photo-oxidized linoleic acid (Frankel, 2005) or by breakdown of unsaturated aldehydes (Schieberle and Grosch, 1981). As BP also formed these aldehydes, it makes sense that $\mathrm{BP}$ creates less of the starting material or produces different products from the same starting materials; namely, the 8-, 9-, 10-, and 11-hydroperoxides. The BP WPC80 with and without color formed higher amounts of 2-pentylfuran compared with HP WPC80, which has been proposed to be formed from the carbon 10-hydroperoxide of linoleic acid (Min et al., 2003).

Each bleaching agent has the potential to form different lipid oxidation products based upon different chemically favored pathways. The reactivity of peroxides proceeds, in most cases, by the hemolytic cleavage of the $\mathrm{O}-\mathrm{O}$ bond, producing free radicals (Benassi et al., 1993). This occurs by thermal decomposition or degradation by metal ions. When the peroxide bond dissociates or decomposes it results in the formation of 2 peroxide radicals. To compare the reactivity of different peroxides it is important to know the bond dissociation energy (BDE) of the $\mathrm{O}-\mathrm{O}$ bond. The kinetic stability of the radical is also important, but the BDE represents the basic chemical behavior of peroxides (Benassi et al., 1993). Benassi et al. (1993) reported peroxides with the structural formula ROOR' to have a higher bond dissociation energy for $\mathrm{R}-\mathrm{O}$ when $\mathrm{R}$ is a phenyl group, as in BP. This results in breakage of the $\mathrm{O}-\mathrm{O}$ peroxide bond, which is weaker than the $\mathrm{R}-\mathrm{O}$ bond yielding 2 benzoyl radical molecules. The BDE of the $\mathrm{O}-\mathrm{O}$ bond of diacyl peroxides, such as $\mathrm{BP}$, has been estimated to be $36.9 \mathrm{kcal} / \mathrm{mol}$ at $25^{\circ} \mathrm{C}$, whereas that of the $\mathrm{O}-\mathrm{O}$ bond in HP has been reported to be $50.5 \mathrm{kcal} /$ mol at $25^{\circ} \mathrm{C}$ (Bach et al., 1996). Hydrogen peroxide is more stable than $\mathrm{BP}$ at the same temperature, meaning that $\mathrm{BP}$ will break into radicals more readily than HP. The decomposition of HP into radicals will require additional thermal energy or a transition metal catalyst (Benassi et al., 1993). Listiyani et al. (2012) reported that $\mathrm{BP}$ was more effective at bleaching fluid whey at $4^{\circ} \mathrm{C}$ than $\mathrm{HP}$, consistent with the respective BDE of BP and HP.

Hydrogen peroxide can break down into 2 types of free radicals: $\cdot \mathrm{OOH}$ and $\cdot \mathrm{OH}$, where the hydroxyl radical $(\cdot \mathrm{OH})$ is one of the most reactive species known (McClements and Decker, 2008). Benzoyl peroxide produces benzoyl radicals by homolytic cleavage of the 
$\mathrm{O}-\mathrm{O}$ bonds, yielding 2 benzoic acid molecules. The free radicals will then abstract a hydrogen from a fatty acid to form a fatty acid radical, which can then form peroxy radicals, hydroperoxides, and new hydrocarbon radicals. The radicals can then attack other fatty acids, continuing the radical formation. The process ends with the termination step where 2 radicals will interact to form aldehydes, ketones, alcohols, and hydrocarbons from the $\beta$-scission reaction. Factors that can affect the decomposition of hydroperoxides in the termination step include temperature of oxidation, metal catalysts, stability of volatile products, and competing secondary reactions (Frankel, 2005). All of the possible different combinations of reactions are responsible for the final distribution of volatile compounds from each bleaching treatment.

The iron concentration of HP WPC with and without color was lower compared with that of the unbleached and BP treatments. Listiyani et al. (2011) also reported iron levels to be lower for WPC34 from HP-bleached whey compared with control WPC34 but not lower than WPC34 from BP-bleached whey. We found a lower final concentration of iron in HP WPC80; it is possible that iron is catalyzing HP decomposition, allowing for radical production. Hydrogen peroxide creates more active radicals (the hydroxyl radical), and the more reactive radicals could explain the increased off-flavor development of the HP-bleached treatments. The decrease in iron from the HP WPC 80 might have been due to iron participating in a Fenton-type reaction. The classic Fenton reaction occurs when ferrous iron reacts with hydrogen peroxide to form ferric ions and, in the process, produces hydroxyl radicals (Damodaran, 2008). This reaction could increase the overall concentration of the hydroxyl radicals, which would then accelerate lipid oxidation. Peroxidation of linoleic acid is catalyzed by Fenton reagents $\mathrm{HP}$ and $\mathrm{Fe}^{2+}$ (Fukuzawa and Fujii, 1992; Damodaran, 2008). Lipid oxidation has a lag period before off-flavors develop (Frankel, 2005; Whitson et al., 2010). The presence of prooxidants, such as iron, can decrease the lag phase, which increases the formation of off-flavors. The decrease of iron in the final HP-bleached WPC80 product could also be due to denaturation of protein, such as lactoferrin, resulting in a release of ferric ions, and therefore the iron passes directly into the permeate during filtration due to damage to the binding sites (Damodaran, 2008).

\section{Functionality}

Foaming is a functional property frequently encountered in WPC80, although it is highly variable (de La Fuente et al., 2002; Foegeding et al., 2002). Lack of foaming can be due to a variety of factors, including fat content, but other antifoaming agents exist in whey or are created as a result of milk or whey processing or cheese manufacture (de La Fuente et al., 2002). Foaming was not observed in the liquid retentates from both controls (annatto and no color). The control liquid retentates had $95 \%$ soluble protein at $\mathrm{pH} 7.0$ and $85 \%$ soluble protein at $\mathrm{pH} 4.6$, and solubility was not different between liquid retentates and spray-dried products $(P>0.05)$. These results confirm that protein denaturation during spray drying was not the source of lack of foaming in the dried WPC80. At pH 7 without heating, all WPC80 had almost entirely soluble protein. After $10 \mathrm{~min}$ of heating, both the colored and uncolored no-bleach and BP WPC80 gelled; therefore, turbidity and solubility could not be measured. The colored and uncolored HP WPC80 had a significant amount of soluble protein after 10 min of heating. After 20 min of heating, both HP treatments gelled. The supernatant of the control (no heat) WPC80 and the 10-min-heated HP WPC80 were adjusted to $\mathrm{pH} 4.6$ and again measured for turbidity and solubility. As would be expected at this $\mathrm{pH}$, the solubility of all treatments decreased. The most interesting observation was that after 10 min, heated HP WPC80 still had soluble protein after the $\mathrm{pH}$ adjustment. $\mathrm{A} \mathrm{pH}$ of 4.6 was chosen because insoluble protein material at $\mathrm{pH} 4.6$ was shown to contribute to gelation (Puyol et al., 1999).

The more damage done to the protein during bleaching or other processing steps, the more aggregation and possibly gelation would be observed from heating. Because the unbleached WPC80 gelled with the same heat treatment as BP, we cannot conclude at this point that BP denatures the protein more compared with HP. We can state, however, that the HP and BP bleaching treatments affected the protein differently. Benzoyl peroxide was previously reported to alter the electrophoretic patterns of whey proteins from blue cheese made from milk bleached with BP (Washam et al., 1974). This effect was amplified when the cheesemilk was heated. Grindrod and Nickerson (1967) reported that HP in skim milk resulted in a decrease in whey protein nitrogen and an increase in NPN after exposure to a $0.5 \%$ and $1.0 \% \mathrm{HP}$ solution at $49.9^{\circ} \mathrm{C}$. The increased HP concentration resulted in an increase in NPN. Cooney and Morr (1972) reported that proteose peptones were the most susceptible to alteration by HP, followed by immunoglobulins, $\beta$-lactoglobulin, and BSA; $\alpha$-lactalbumin was the least susceptible to HP. Schmidt (1983) reported that HP-treated WPC had altered methionine and cystine/cysteine concentrations, which was thought to affect gelation properties due to the importance of disulfide bonds. If HP bleaching were not damaging the protein during processing, then it would make sense that the unbleached WPC80 would 
have also exhibited similar behavior to the WPC80 from HP-bleached whey. This result was not observed. What seems more likely is that HP damaged the protein differently than BP and the unbleached WPC80, perhaps by creating smaller fractions of protein, which were unable to align quickly and gel within the $10 \mathrm{~min}$ of heating. After a whey protein is heat denatured, the unfolded protein will aggregate and form a network based upon electrostatic interactions, disulfide bonds, and hydrophobic interactions. If the HP denatured the protein into smaller fragments, it would take more time for the fragments to aggregate and align to form a gel. If sulfur-containing amino acids are being damaged, this could affect disulfide bond formation and subsequent flavor development. Hydrogen peroxide appears to improve the heat stability temperature of the whey protein, which may enhance functionality; however, it is unclear if the amino acids are damaged, which would then affect the nutritional value. Further investigation into the effects of each bleaching method on protein should be explored.

\section{CONCLUSIONS}

Both HP and BP are viable bleaching agents for Cheddar cheese whey. Higher off-flavor intensities and lipid oxidation associated with HP bleaching suggest that concentrations and time should be optimized and carefully applied. Benzoyl peroxide creates less offflavors and bleaches fluid whey more efficiently than HP. Benzoyl peroxide is not currently an approved bleaching agent for whey products in China or Japan. Hydrogen peroxide may improve the heat stability of rehydrated WPC80, potentially enhancing its functionality in heat-treated products.

\section{ACKNOWLEDGMENTS}

The authors thank the New York State Milk Promotion Board (Albany, NY), the Dairy Research Institute (managed by DMI, Rosemont, IL), and the Northeast Dairy Foods Research Center (Cornell University, Ithaca, NY)for partial funding of this research. We acknowledge the technical assistance of Michael Adams, Irma Amelia, Steve Beckman, Tom Burke, Maureen Chapman, Chassidy Coon, Aneela Hameed, Jessica Mallozzi, and Mark Newbold from the Department of Food Science at Cornell University, the staff of the Cornell Dairy Plant, and Paige Luck from the Department of Food Bioprocessing and Nutrition Sciences at North Carolina State University (Raleigh) for developing the solubility and heat-stability methods. The use of trade names does not imply endorsement nor lack of endorsement by those not mentioned.

\section{REFERENCES}

AOAC. 2000. Official Methods of Analysis. 17th ed. AOAC, Gaithersburg, MD.

Bach, R. D., P. Y. Ayala, and H. B. Schlegel. 1996. A reassessment of the bond dissociation energies of peroxides. An ab initio study. J. Am. Chem. Soc. 118:12758-12765.

Benassi, R., U. Folli, S. Sbardellati, and F. Taddei. 1993. Conformational properties and homolytic bond cleavage of organic peroxides. I. An empirical approach based upon molecular mechanics and $a b$ initio calculations. J. Comput. Chem. 14:379-391.

Cadwallader, K. R., and T. Singh. 2009. Flavours and off-flavours in milk and dairy products. Pages 631-690 in Advanced Dairy Chemistry. Vol. 3: Lactose, Water, Salts and Minor Constituents. P. L. H. McSweeney and P. F. Fox, ed. Springer Science LLC, New York, NY.

Campbell, R. E., R. E. Miracle, and M. A. Drake. 2011a. The impact of starter culture and annatto on the flavor and functionality of whey protein concentrate. J. Dairy Sci. 94:1185-1193.

Campbell, R. E., R. E. Miracle, P. D. Gerard, and M. A. Drake. 2011b. The effect of starter culture and storage on the flavor of liquid whey. J. Food Sci. 76:S354-S361.

Carunchia Whetstine, M. E., K. R. Cadwallader, and M. A. Drake. 2005a. Characterization of aroma compounds responsible for rosy floral in Cheddar cheese. J. Agric. Food Chem. 53:3126-3132.

Carunchia Whetstine, M. E., A. E. Croissant, and M. A. Drake. 2005b. Characterization of dried whey protein concentrate and isolate flavor. J. Dairy Sci. 88:3826-3839.

Carunchia Whetstine, M. E., J. D. Parker, M. A. Drake, and D. K. Larick. 2003. Determining flavor and flavor variability in commercially produced liquid Cheddar whey. J. Dairy Sci. 86:439-448.

Cooney, C. M., and C. V. Morr. 1972. Hydrogen peroxide alteration of whey proteins in whey and concentrated whey systems. J. Dairy Sci. 55:567-573.

Croissant, A. E., E. J. Kang, R. E. Campbell, E. Bastian, and M. A. Drake. 2009. The effect of bleaching agent on the flavor of liquid whey and whey protein concentrate. J. Dairy Sci. 92:5917-5927.

Damodaran, S. 2008. Lipids. Pages 194- 195 in Fennema's Food Chemistry. 4th ed. S. Damodaran, K. L. Parkin, and O. R. Fennema, ed. CRC Press, Boca Raton, FL.

Dannacher, J. J. 2006. Catalytic bleach: Most valuable applications for smart oxidation chemistry. J. Mol. Catal. Chem. 251:159-176.

Davis, J. P., and E. A. Foegeding. 2007. Comparisons of the foaming and interfacial properties of whey protein isolate and egg white proteins colloids and surfaces. Colloids Surf. Biointerf. 54:200210.

de La Fuente, M. A., Y. Hemar, M. Tamehana, P. A. Munro, and H. Singh. 2002. Process induced changes in whey proteins during the manufacture of whey protein concentrates. Int. Dairy J. $12: 361-369$.

Dickinson, E. 1999. Adsorbed protein layers at fluid interfaces: Interactions, structure and surface rheology. Colloid Surf. Biointerf. 15:161-176.

Drake, M. A. 2006. Flavor and flavor carry-through of whey proteins in beverages. Pages 292-300 in The Wonders of Whey... Catch the Power: Proc. 4th Int. Whey Conf. American Dairy Products Institute, Elmhurst, IL.

Drake, M. A., and G. V. Civille. 2003. Flavor lexicons. Compr. Rev. Food Sci. Food Safety 2:33-40.

Drake, M. A., Y. Karagul-Yuceer, K. R. Cadwallader, G. V. Civille, and P. S. Tong. 2003. Determination of the sensory attributes of dried milk powders and dairy ingredients. J. Sens. Stud. 18:199216

Drake, M. A., R. E. Miracle, and J. M. Wright. 2009. Sensory properties of dairy proteins. Pages 429-448 in Milk Proteins: From Expression to Food. A. Thompson, M. Boland, and H. Singh, ed. Elsevier, Amsterdam, the Netherlands.

Dzuy, N. Q., and D. V. Boger. 1983. Yield stress measurement for concentrated suspensions. J. Rheol. (N.Y.N.Y.) 27:321-349.

Dzuy, N. Q., and D. V. Boger. 1985. Direct yield stress measurement with the vane method. J. Rheol. (N.Y.N.Y.) 29:335-347. 
Evans, J. P., J. Zulewska, M. Newbold, M. A. Drake, and D. M. Barbano. 2009. Comparison of composition, sensory and volatile components of thirty four percent whey protein and serum protein concentrates. J. Dairy Sci. 92:4773-4791.

Evans, J. P., J. Zulewska, M. Newbold, M. A. Drake, and D. M. Barbano. 2010. Comparison of composition and sensory properties of $80 \%$ whey protein and milk serum protein concentrates. J. Dairy Sci. 93:1824-1843.

Foegeding, E. A., J. P. Davis, D. Doucet, and M. McGuffey. 2002. Advances in modifying and understanding whey protein functionality. Trends Food Sci. Technol. 13:151-159.

Frankel, E. N. 2005. Chapter 4: Hydroperoxide decomposition (pages 55-78) and Chapter 10: Foods (pages 187-226) in Oxidation. 2nd ed. The Oily Press/PJ Barnes and Associates, Bridgewater, UK.

Fukuzawa, K., and T. Fujii. 1992. Peroxide dependent and independent lipid peroxidation: Site-specific mechanisms of initiation by chelated iron and inhibition by $\alpha$-tocopherol. Lipids 27:227-233.

Gallardo-Escamilla, F. J., A. L. Kelly, and C. M. Delahunty. 2005. Sensory characteristics and related volatile flavor compound profiles of different types of whey. J. Dairy Sci. 88:2689-2699.

Grindrod, J., and T. A. Nickerson. 1967. Changes in milk proteins treated with hydrogen peroxide. J. Dairy Sci. 50:142-146.

Kaylegian, K. E., G. E. Houghton, J. M. Lynch, J. R. Fleming, and D. M. Barbano. 2006. Calibration of infrared milk analyzers: Modified milk versus producer milk. J. Dairy Sci. 89:2817-2832.

Listiyani, M. A. D., R. E. Campbell, D. M. Barbano, P. D. Geard, and M. A. Drake. 2012. Effect of temperature and bleaching agent on bleaching of liquid Cheddar whey. J. Dairy Sci. 95:36-49.

Listiyani, M. A. D., R. E. Campbell, R. E. Miracle, L. O. Dean, and M. A. Drake. 2011. Influence of bleaching on flavor of $34 \%$ whey protein concentrate and residual benzoic acid concentration in dried whey proteins. J. Dairy Sci. 94:4347-4359.

Lloyd, M. A., M. A. Drake, and P. D. Gerard. 2009. Flavor variability and flavor stability of U.S.-produced whole milk powder. J. Food Sci. 74:S334-S343.

Luck, P. J., N. Bray, and E. A. Foegeding. 2001. Factors determining yield stress and overrun of whey protein foams. J. Food Sci. 67:1677-1681.

McClements, D. J., and E. A. Decker. 2008. Lipids. Pages 155-216 in Fennema's Food Chemistry. 4th ed. S. Damodaran, K. L. Parkin, and O. R. Fennema, ed. CRC Press, Boca Raton, FL.

Meilgaard, M. M., G. V. Civille, and B. T. Carr. 1999. The spectrum descriptive analysis method. Pages 189-254 in Sensory Evaluation Techniques. 4th ed. CRC Press, Boca Raton, FL.

Mercadante, A. Z. 2008. Analysis of carotenoids. Pages 447-478 in Food Colorants: Chemical and Functional Properties. C. Socaciu, ed. CRC Press, Boca Raton, FL.

Min, D. B., A. L. Callison, and H. O. Lee. 2003. Singlet oxygen oxidation for 2-pentylfuran and 2-pentenyfuran formation in soybean oil. J. Food Sci. 68:1175-1178.
NIST. 2005. Wiley Registry: NIST Mass Spectral Library. 8th ed Wiley, Hoboken, NJ.

Pernell, C. W., E. A. Foegeding, and C. R. Daubert. 2000. Measurement of the yield stress of protein foams by vane rheometry. J. Food Sci. 65:110-114

Phillips, L. G., J. B. German, T. E. O'Neill, E. A. Foegeding, V. R. Harwalkar, A. Kilara, B. A. Lewis, M. E. Mangino, C. V. Morr, J. M. Regenstein, D. M. Smith, and J. E. Kinsella. 1990. Standardized procedure for measuring foaming properties of three proteins: A collaborative study. J. Food Sci. 55:1441-1444.

Puyol, P., P. F. Cotter, and D. M. Mulvihill. 1999. Thermal gelation of commercial whey protein concentrate: Influence of $\mathrm{pH} 4.6 \mathrm{insolu}-$ ble protein on thermal gelation. Int. J. Dairy Technol. 52:81-91.

Schieberle, P., and W. Grosch. 1981. Model experiments about the formation of volatile carbonyl compounds. J. Am. Oil Chem. Soc. 58:602-607.

Schmidt, R. H. 1983. Effect of processing on whey protein functionality. J. Dairy Sci. 67:2723-2733.

Scotter, M. 2009. The chemistry and analysis of annatto food colouring: A review. Food Addit. Contam. 26:1123-1145.

Steffe, J. F. 1996. Rheological Methods in Food Process Engineering. 2nd ed. Freeman Press, East Lansing, MI.

Tomaino, R. M., L. G. Turner, and D. K. Larick. 2004. The effect of Lactococcus lactis starter cultures on the oxidative stability of liquid whey. J. Dairy Sci. 87:300-307.

USDEC. 2008. Whey products. United States Dairy Export Council. Accessed Jan. 21, 2011. http://www.usdec.org/Products/content. cfm? ItemNumber $=82498 \&$ navItemNumber $=82257$.

US FDA. 2009. 21 CFR 184.1366: Hydrogen peroxide. Accessed Aug. 10, 2011. http://www.accessdata.fda.gov/scripts/cdrh/cfdocs/cfcfr/CFRSearch.cfm?fr $=184.1366$.

Van den Dool, H., and P. Kratz. 1963. A generalization of the retention index system including linear programmed gas liquid partition chromatography. J. Chromatogr. 11:463-471.

Washam, C. J., G. W. Reinhold, E. R. Vedamuthu, and R. Jorgenson. 1974. Changes in milk, whey, and blue cheese as induced by benzoyl peroxide. J. Milk Food Technol. 37:244-249.

Whitson, M. E., R. E. Miracle, and M. A. Drake. 2010. Sensory characterization of chemical components responsible for cardboard flavor in whey protein. J. Sens. Stud. 25:616-636.

Wilde, P. J. 2000. Interfaces: Their role in foam and emulsion behavior. Curr. Opin. Colloid Interface Sci. 5:176-181.

Wright, B. J., S. E. Zevchak, J. M. Wright, and M. A. Drake. 2009. The impact of agglomeration and storage on flavor and flavor stability of whey protein concentrate 80 and whey protein isolate. J. Food Sci. 74:S17-S29.

Wright, J. W., M. E. Carunchia-Whetstine, R. E. Miracle, and M. A. Drake. 2006. Characterization of cabbage off-flavor in whey protein isolate. J. Food Sci. 71:C86-C90. 